\title{
Aircraft measurements of aerosol black carbon from a coastal location in the north-east part of peninsular India during ICARB
}

\author{
S Suresh Babu ${ }^{1}$, S K Satheesh ${ }^{2}$, K Krishna Moorthy ${ }^{1}$, C B S Dutt ${ }^{3}$, \\ Vijayakumar $S$ NaIR $^{1}$, Denny P Alappattu ${ }^{1}$ and P K Kunhikrishnan ${ }^{1}$ \\ ${ }^{1}$ Space Physics Laboratory, VSSC, Trivandrum 695 022, India. \\ ${ }^{2}$ Centre for Atmospheric and Oceanic Sciences, Indian Institute of Science, Bangalore 560 012, India. \\ ${ }^{3}$ Indian Space Research Organisation Head Quarters, Antariksh Bhavan, New BEL Road, \\ Bangalore 560 094, India.
}

\begin{abstract}
During the Integrated Campaign for Aerosols, gases and Radiation Budget (ICARB) over India, high-resolution airborne measurements of the altitude profiles of the mass concentrations $\left(\mathrm{M}_{\mathrm{B}}\right)$ of aerosol black carbon (BC) were made off Bhubaneswar $\left(\mathrm{BBR}, 85.82^{\circ} \mathrm{E}, 20.25^{\circ} \mathrm{N}\right)$, over northwest Bay of Bengal, in the altitude region upto $3 \mathrm{~km}$. Such high-resolution measurements of altitude profiles of aerosols are done for the first time over India. The profiles showed a near-steady vertical distribution of $\mathrm{M}_{\mathrm{B}}$ modulated with two small peaks, one at $800 \mathrm{~m}$ and the other at $\sim 2000 \mathrm{~m}$. High resolution GPS (Global Positioning System) sonde (Vaisala) measurements around the same region onboard the research vessel Sagar Kanya (around the same time of the aircraft sortie) revealed two convectively well mixed layers, one from ground to $\sim 700 \mathrm{~m}$ with an inversion at the top and the other extends from $1200 \mathrm{~m}$ to $\sim 2000 \mathrm{~m}$ with a second inversion at $\sim 2200 \mathrm{~m}$ and a convectively stable region in the altitude range 700-1200 $\mathrm{m}$. The observed peaks in the $\mathrm{M}_{\mathrm{B}}$ profile are found to be associated with these temperature inversions. In addition, long-range transport from the IndoGangetic Plain (IGP) and deserts lying further to the west also influence the vertical profile of BC. Latitudinal variation of $\mathrm{M}_{\mathrm{B}}$ showed a remarkable land ocean contrast at the $500 \mathrm{~m}$ altitude (within the well mixed region) with remarkably lower values over oceans, suggesting the impact of strong sources over the mainland. However, above the ABL (at $1500 \mathrm{~m}$ ), the latitudinal variations were quite weak, and this appears to be resulting from the impact of long-range transport. Comparison of the altitude profiles of $\mathrm{M}_{\mathrm{B}}$ over $\mathrm{BoB}$ off $\mathrm{BBR}$ with those obtained during the earlier occasion over the inland stations of Hyderabad and Kanpur showed similarities above $\sim 500 \mathrm{~m}$, with $\mathrm{M}_{\mathrm{B}}$ remaining around a steady value of $\sim 1 \mu \mathrm{g} \mathrm{m}^{-3}$. However, large differences are seen within the ABL. Even though the observed $\mathrm{M}_{\mathrm{B}}$ values are not unusually high, their near constancy in the vertical column will have important implications to radiative forcing.
\end{abstract}

\section{Introduction}

Aerosol black carbon (BC) or soot, the byproduct of all incomplete combustion processes, is believed to be mostly of anthropogenic origin and is generally in the fine, submicron size range. As such, it has a long atmospheric lifetime (e.g., Babu and Moorthy 2002) making them amenable for easy transport both horizontally, and vertically to higher regions of the atmosphere. In the nascent form, graphitic carbon is hydrophobic, but eventually becomes hydrophilic by oxidation or after coating by soluble aerosols such as sulfate and organics. Thus, a significant fraction of $\mathrm{BC}$ can

Keywords. Aerosol black carbon; vertical profile; ICARB. 
be in an internally mixed state in the atmosphere, which affects its nucleation and optical properties (Möhler et al 2005) and makes the quantification of its impact on climate difficult (Clarke et al 2004). Because of its strong absorption over a wide range of wavelengths, $\mathrm{BC}$ contributes significantly to atmospheric warming (Jacobson 2001) and its forcing potential strongly depends on the vertical profile (Haywood and Ramaswamy 1998; Satheesh 2002). It also contributes to indirect forcing of climate by acting as cloud condensation nuclei (Lohmann et al 2000). The presence of BC aerosols are identified and even quantified (even though in a limited way) in upper troposphere and lower stratosphere (Pueschel et al 1992; Blake and Kato 1995; Strawa et al 1999). Thus the study of vertical distribution of $\mathrm{BC}$ has immense relevance in aerosol characterization. Despite, available information is limited even globally and especially over India except for a few recent efforts (Moorthy et al 2004; Tripathi et al 2005).

During the Integrated Campaign for Aerosol gases Radiation Budget (ICARB, Moorthy et al 2006 and this issue) extensive observations on the altitude profiles of $\mathrm{BC}$ were made in the lower troposphere (upto $3 \mathrm{~km}$ from ground) onboard a propeller aircraft (beechcraft 20) of the National Remote Sensing Agency (NRSA). In all, 26 sorties were made from 5 bases during the campaign; two each along the east (Bhubaneswar and Chennai) and west coasts (Thiruvananthapuram and Goa) and one from the inland station Hyderabad. In this paper, we present the results obtained from the measurement of the altitude variation of $\mathrm{BC}$ off Bhubaneswar $\left(\mathrm{BBR}, 85.82^{\circ} \mathrm{E}, 20.25^{\circ} \mathrm{N}\right)$, over the Bay of Bengal (BoB) in the east coast of India.

\section{Experimental setup}

The black carbon mass concentration $\left(\mathrm{M}_{\mathrm{B}}\right)$ measurements were made using a portable, single channel, aethalometer (model AE 42 of Magee Scientific, Hansen et al 1996). It is a simple, rugged instrument for field experiments of long duration and provided data almost without a break. The details of the sampling technique and configuring the aethalometer in an aircraft are available in Moorthy et al (2004) and Tripathi et al (2005). The instrument was mounted inside the cabin of the aircraft, which was kept unpressurised. The ambient air was aspirated through a stainless steel pipe, fitted to the body of the aircraft under its nose, such that the inlet opens into the incoming air as the aircraft flies. The instantaneous position of the aircraft at every second was recorded using a global positioning system (GPS). The flight tracks

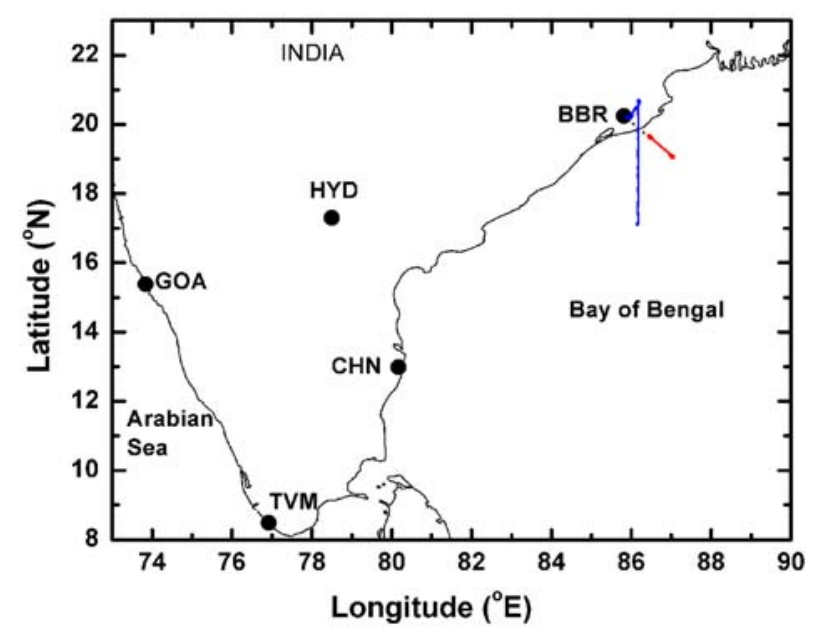

Figure 1. The flight paths of the aircraft from Bhubaneswar. The red line corresponds to the track in which the high resolution vertical profiling was done at 8 levels and the blue line corresponds to the sortie used for examining latitudinal gradient at two altitudes.

of the sorties performed from BBR are shown in figure 1. The inlets of the instrument was connected to the pipe using a Teflon tube, $\sim 1.5 \mathrm{~m}$ long. The aethalometer estimated $\mathrm{M}_{\mathrm{B}}$ by measuring the change in the transmittance of its quartz filter tape on to which the particles impinge. The flow rate was determined by its internal pump operated under standard mass flow condition and the timebase is programmable. The measured concentrations were corrected for the change in pumping speed caused by change in the ambient pressure as the aircraft climbs to different height levels following the principle outlined in Moorthy et al (2004). Reports are available in the recent literature on uncertainties in the aethalometer estimated BC (for e.g., Weingartner et al 2003; Arnott et al 2005; Sheridan et al 2005 and Corrigan et al 2006) with several suggestions to account for it and these were followed in analyzing the data. In the present case we used an amplification factor of 1.9 and an 'R' factor (shadowing effect) of 0.88 .

During the flight off BBR, the aethalometer was operated at a time base of $2 \mathrm{~min}$ and a flow rate of 6.5 standard litres per minute (under standard temperature $\left(T_{0}, 293 \mathrm{~K}\right)$ and pressure $\left(P_{0}\right.$, $1017 \mathrm{hPa})$ ). However, because the ambient pressure decreases while the aircraft climbs higher, the pumping speed increases to maintain the set mass flow rate, and as such, more volume of air is aspirated. The actual volume $V$ of air aspirated at an ambient pressure $P$ and temperature $T$ is thus

$$
V=V_{0} \cdot \frac{P_{0}}{P} \cdot \frac{T}{T_{0}}
$$


Since the measured $\mathrm{BC}$ concentrations $\left(\mathrm{M}_{\mathrm{B}}^{*}\right)$ are calculated based on standard flow rate $V_{0}$, the actual $\mathrm{BC}$ concentration $\mathrm{M}_{\mathrm{B}}$, after correcting for the change in flow rate, is:

$$
\mathrm{M}_{\mathrm{B}}=\mathrm{M}_{\mathrm{B}}^{*}\left[\frac{P_{0} T}{P T_{0}}\right]^{-1}
$$

Following the above equation, each measurement of $\mathrm{M}_{\mathrm{B}}^{*}$ was converted to the true $\mathrm{BC}$ concentration $\mathrm{M}_{\mathrm{B}}$.

The aircraft sorties were made from Bhubaneswar $\left(\mathrm{BBR}, 85.82^{\circ} \mathrm{E}, 20.25^{\circ} \mathrm{N}\right)$, an urban location located towards the east coast of India and very close to the eastern end of Indo-Gangetic Plain. The eastern part of Indo-Gangetic Plain is 'the coal belt' of India and has a cluster of coal-based thermal power plants, which are considered as significant emitters of BC aerosols in this region (Nair et al 2007). In addition, the vehicular emission as well as the domestic activities in and around the urban area of BBR also contribute to the $\mathrm{BC}$ concentration near the sampling site.

\section{Results and discussion}

\subsection{Altitude profile of $M_{\mathrm{B}}$}

In general, all airborne measurements were carried out during the period 09:30 to 12:30 LT. This means that the observations commenced nearly four hours after the local sunrise ( 05:30LT). Thus the boundary layer has fully developed and strong convective motions have set in by the time profiling has started. The ambient temperatures were in the range 35 to $40^{\circ} \mathrm{C}$ at the $\mathrm{BBR}$ airport during this period, implying strong thermal convections. The altitude distribution of $\mathrm{M}_{\mathrm{B}}$ (after the correction mentioned earlier) from the aircraft measurement made on 28 March 2006 is shown in figure 2. On this day, the flight took off at 09:26 LT and leveled at an altitude of $500 \mathrm{~m}$, about $50 \mathrm{~km}$ off the coast. The profiling was done over the ocean $(\mathrm{BoB})$ at eight different levels (namely $500 \mathrm{~m}$, $800 \mathrm{~m}, 1100 \mathrm{~m}, 1400 \mathrm{~m}, 1700 \mathrm{~m}, 2000 \mathrm{~m}, 2500 \mathrm{~m}$ and $3000 \mathrm{~m}$ above AGL (average ground level)) to get a good height resolution (which was not available in earlier measurements, Moorthy et al 2004; Tripathi et al 2005). At each level, the aircraft flew steadily for about $12 \mathrm{~min}$, and the data obtained during this period are corrected using equation (2) and averaged to obtain the mean value representing that altitude. This procedure was repeated at each altitude. The data obtained during the aircraft manoeuvers were rejected (Moorthy et al

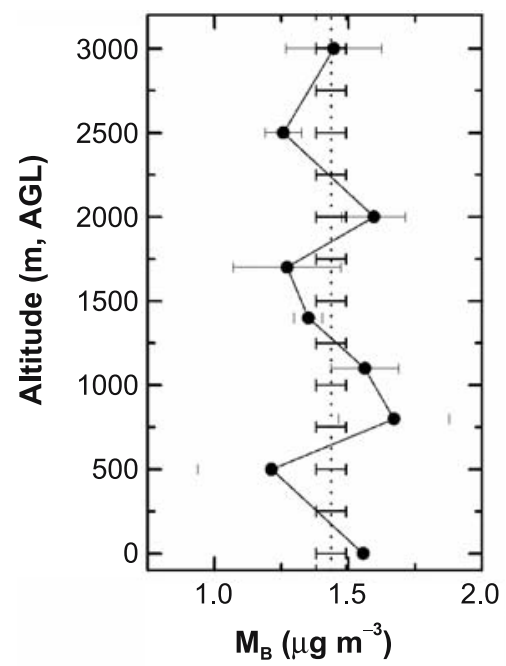

Figure 2. Altitude profile of $\mathrm{M}_{\mathrm{B}}$ off BBR on 28 March 2006 . The points are mean concentration at each level and the bars through them are the standard errors. The dotted vertical line with horizontal bar shows the column mean value of $\mathrm{M}_{\mathrm{B}}$ with standard error.

2004). The solid circles in figure 2 represent this mean value at each altitude level, and the horizontal bars through the points represent the standard error of the mean, a statistical parameter signifying the uncertainty in $M_{B}$ at the respective heights due to the natural atmospheric variabilities. These are much higher than the intrinsic errors in the instrument. During the same period, independent measurements of $\mathrm{M}_{\mathrm{B}}$ were also being made onboard the ship ORV Sagar Kanya, along the coastal water off BBR as part of the ocean segment of ICARB (Moorthy et al this issue) using another aethalometer, which was intercompared with the one onboard the aircraft before the campaign under the same ambient conditions. The surface level value of $M_{B}$ (for ' 0 ' altitude) is obtained as the average of the shipboard measurements conducted in the same region, on days closest to the sortie.

The altitude distribution of $\mathrm{M}_{\mathrm{B}}$ in figure 2 shows a near steady vertical distribution with two small peaks at $800 \mathrm{~m}$ and $2000 \mathrm{~m}$. The mean value of $\mathrm{M}_{\mathrm{B}}$ (for the entire altitude range) was $1.43 \pm$ $0.06 \mu \mathrm{g} \mathrm{m}^{-3}$ and this is shown by the vertical dotted line in figure 2 with the horizontal bars on it representing the standard deviation of the mean. The peaks and valleys in the profile, though not highly developed, are significant deviations from the mean. The figure reveals several interesting features.

- At the surface level (over the ocean) $\mathrm{M}_{\mathrm{B}}$ is $\geq 1.5 \mu \mathrm{g} \mathrm{m}^{-3}$. It initially decreased with height to reach $1.2 \mu \mathrm{g} \mathrm{m}^{-3}$ at $500 \mathrm{~m}$ and increased to attain a peak value of $1.7 \mu \mathrm{g} \mathrm{m}^{-3}$ at $\sim 800 \mathrm{~m}$. 


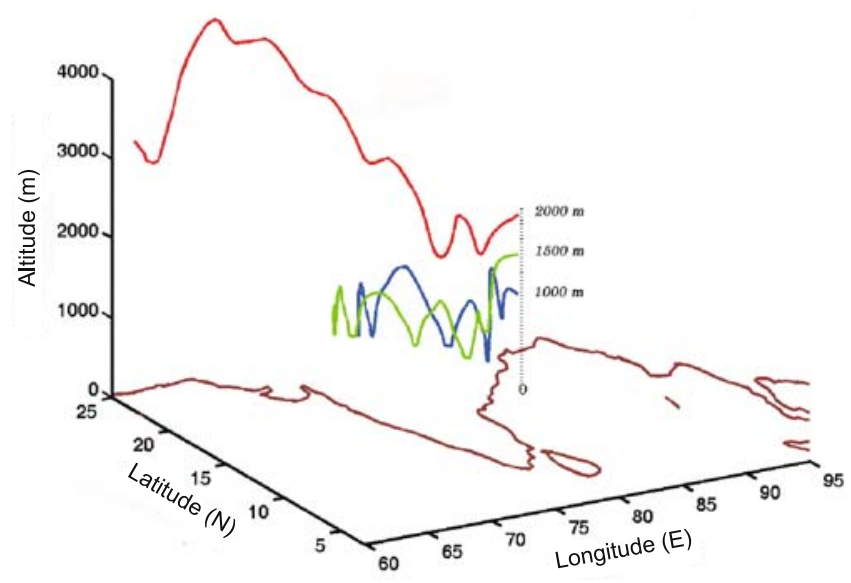

Figure 3. A 3D representation of the 5-day airmass back trajectories arriving at $1000 \mathrm{~m}, 1500 \mathrm{~m}$ and $2000 \mathrm{~m}$ over the region $\left(86.7^{\circ} \mathrm{E}, 19.4^{\circ} \mathrm{N}\right)$ where vertical profiling was done. The study region is projected over to the ocean surface by the dotted line.

- Above $800 \mathrm{~m}, \mathrm{M}_{\mathrm{B}}$ decreased gradually to reach the lowest value of $\sim 1.27 \pm 0.2 \mu \mathrm{g} \mathrm{m}^{-3}$ at $1700 \mathrm{~m}$.

- Above $1700 \mathrm{~m}, \mathrm{M}_{\mathrm{B}}$ again increased and the second peak occurred at $2000 \mathrm{~m}$ above the surface where the value of $\mathrm{M}_{\mathrm{B}}$ was $\sim 1.6 \mu \mathrm{g} \mathrm{m}^{-3}$.

\subsubsection{Role of long-range transport}

Thus, significant amounts of $\mathrm{BC}$ concentrations are observed above $500 \mathrm{~m}$. In order to examine the role of long range transport from potential source regions for the high $\mathrm{BC}$ concentrations above the atmospheric boundary layer $(\mathrm{ABL})$ at these levels, 5-day back trajectories were computed using Hybrid Single Particle Legrangian Integrated Trajectory (HYSPLIT, http://www.arl.noaa.gov/ready/hysplit4.html)

model of the National Oceanic and Atmospheric Administration (NOAA) at $1000 \mathrm{~m}, 1500 \mathrm{~m}$ and $2000 \mathrm{~m}$ above the study location and are shown in figure 3. It shows that the trajectories reaching at $1000 \mathrm{~m}$ and $1500 \mathrm{~m}$ above the surface are originating from the Indo-Gangetic Plains and are traveling mainly through the boundary layer before reaching the study location. In sharp contrast to this, the trajectory at $2000 \mathrm{~m}$, originating from the west Asian region $\left(\sim 60^{\circ} \mathrm{E}\right)$, clearly shows the existence of a pathway, which favours advection of aerosols from west Asia, along northwest and central India to the observing site. It is also important to note that the trajectory originated at $3 \mathrm{~km}$ over west Asia, traveled along the upper region $(>2 \mathrm{~km})$ till it arrived at the measurement site. Thus, there is a significant contribution of (in the free troposphere) aerosols originating at distant sources and subsequently transported horizontally by upper air motions. It is important to note at this juncture that increased advection from the west Asian region resulted in significant increase in AOD over Indo-Gangetic Plain during ICARB (Beegum et al this issue). It is also important to note that even though these $M_{B}$ values are not abnormally high (compared to the surface values) the near-steady nature of the profile up to $3 \mathrm{~km}$ will have important implications to radiative forcing.

Several investigators have reported the existence of aerosol layers with enhanced concentration above the atmospheric boundary layer (ABL) over the Indian region. From the vertical profile of aerosol back scatter measured using micro pulse lidar (MPL) at Visakhapatnam $\left(17.7^{\circ} \mathrm{N}, 83.3^{\circ} \mathrm{E}\right)$ located on the east coast of India (near to the present profiling region), Niranjan et al (2007) reported aerosol layers with increased extinction and having a few kilometer thickness in the height region between 1.6 and $5 \mathrm{~km}$ during the summer months (March-April) of 2005 and 2006. Based on back trajectory analysis, they inferred that these layers are caused by airmasses originated from Arabia during $60 \%$ of the cases, while in the rest of the cases they originated from the Indian subcontinent. Based on the MPL measurements from Bangalore, Satheeshet al (2006) also reported the existence of aerosol layers above the ABL (between 1.0 and $1.5 \mathrm{~km})$.

\subsubsection{Role of the $A B L$}

In the ocean segment of ICARB, regular daily launches of high resolution GPS balloonsondes were made from ORV Sagar Kanya. These provided information on the thermodynamics of the atmosphere upto $\sim 25 \mathrm{~km}$. In figure 4 , we have shown the vertical profiles (upto $3 \mathrm{~km}$ ) of temperature $(T)$, potential temperature $(\theta)$, wind speed $\left(\mathrm{m} \mathrm{s}^{-1}\right)$ and wind direction $\left(^{\circ}\right.$, clockwise from north) obtained closest in space and time to the day of aircraft measurements.

The potential temperature ' $\theta$ ' was calculated as

$$
\theta=T\left(\frac{P_{0}}{P}\right)^{\kappa}
$$

where $\kappa=R / c_{p} ; R$ is the specific gas constant for dry air and $c_{p}$ is the specific heat capacity of dry air at constant pressure.

Figure 4 shows several structures in all these parameters. The most significant are the presence of two strong inversions in $\theta$, one at $\sim 700 \mathrm{~m}$ and the other at $\sim 2200 \mathrm{~m}$, and a less pronounced one at 


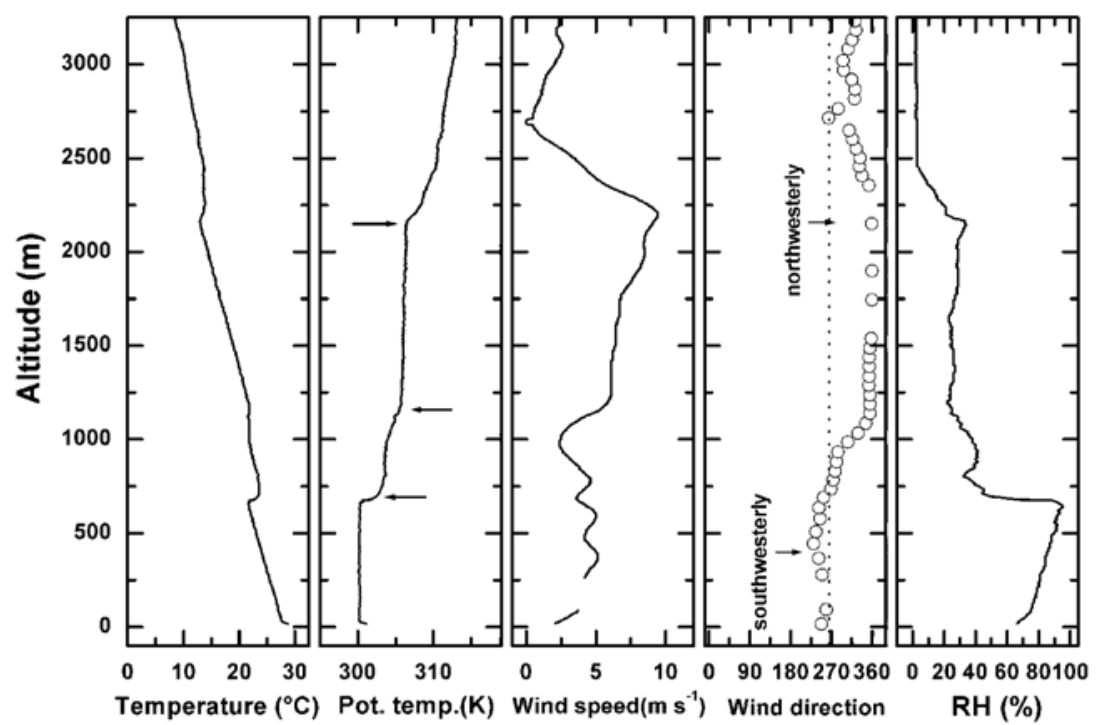

Figure 4. Vertical profile of meteorological parameters obtained from the GPS sonde (Vaisala) measurements off Bhubaneswar. The arrows in the potential temperature panel identify the increases discussed in the text.

$1200 \mathrm{~m}$ (all being identified with arrow marks in the figure). From ground to $700 \mathrm{~m}$ (the region of first inversion in $\theta$ ) the potential temperature remains constant $(300 \mathrm{~K})$ implying an adiabatic condition favouring the prevalence of a convectively wellmixed region, extending upto $700 \mathrm{~m}$. The height of the mixed layer is the altitude of the base of the elevated inversion, which separates the mixed layer from the stable layer above and from the figure it is $700 \mathrm{~m}$. In this region, weak $\left(\sim 4 \mathrm{~m} \mathrm{~s}^{-1}\right)$ southwesterly winds are observed. Above that $\theta$ increases with altitude showing a sub-adiabatic lapse rate and a convectively stable atmospheric region upto $1200 \mathrm{~m}$. Above $1200 \mathrm{~m}$, the lapse rate again changes to adiabatic condition $(\theta$ is steady with altitude), which extends upto $\sim 2100 \mathrm{~m}$. In this region, the wind speeds are higher (up to $\sim 10 \mathrm{~ms}^{-1}$ ) (as compared to the weak southwesterly winds $\left(\sim 4 \mathrm{~ms}^{-1}\right)$ in the mixed layer below), and are basically westerlies/northwesterlies implying strong advection from the dry landmass even beyond $3 \mathrm{~km}$. The sharp decrease in relative humidity $(\mathrm{RH})$ above $700 \mathrm{~m}$, in figure 4, also corroborates advection of a dry airmass in this region. This, along with the back trajectory at $2000 \mathrm{~m}$ level in figure 3 leads strong support to the presence of a different airmass probably associated with long-range transport from the western dryarid and semi-arid regions. The convective region below and the elevated inversion above (which act as a lid) significantly dampening vertical mixing of air and aerosols and favours transport to long distances. The presence of such long range transport has also been reported at Chennai, well down BBR in the east coast of India by Moorthy et al

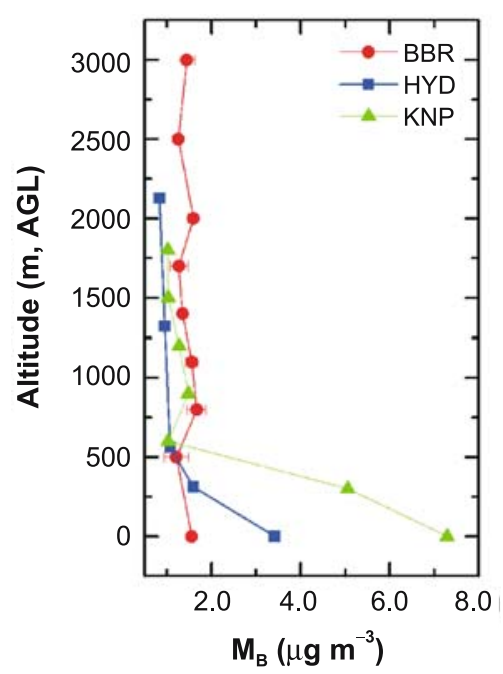

Figure 5. Comparison of the altitude profile of $\mathrm{BC}$ observed over BoB off BBR with those obtained over Hyderabad (blue line with square symbol) and Kanpur (green line with triangle) during earlier airborne measurements.

(this issue) based on lidar and back trajectory analysis.

\subsection{Comparison of the profile off $B B R$ with earlier measurements over inland stations}

A comparison of $\mathrm{M}_{\mathrm{B}}$ profile obtained off $\mathrm{BBR}$ over the BoB with those obtained over Kanpur (Tripathi et al 2005) and Hyderabad (Moorthy et al 2004), in different years, but almost in the same seasons, during the forenoon hours is shown in figure 5. At Hyderabad, the ABL extends upto 
$\sim 800 \mathrm{~m}$ during the profiling; but there was no indication of long-range transport. At Kanpur, there was an elevated layer of enhanced BC at $\sim 1 \mathrm{~km}$, which was attributed to long-range transport (Tripathi et al 2005). However, while comparing these profiles over different regions, it is to be borne in mind that the atmospheric measurements are subject to inherent large, natural variabilities. In order to have a statistically significant data, which represents a particular region in a given season, an average of the large number of such measurements from the same region spanning the entire season is always better. Nevertheless, it is important to note the most striking difference of the profile off BBR as revealed by the limited observations, which are:

- Over Hyderabad and Kanpur, $\mathrm{M}_{\mathrm{B}}$ showed a sharp decrease with height from the surface upto $\sim 500 \mathrm{~m}$. While at Hyderabad, the decrease in $\mathrm{M}_{\mathrm{B}}$ was from $\sim 3.5 \mu \mathrm{g} \mathrm{m}^{-3}$ at the surface to $\sim 1 \mu \mathrm{g} \mathrm{m}^{-3}$ at $500 \mathrm{~m}$, at KNP it was much more sharp, from $7 \mu \mathrm{g} \mathrm{m}^{-3}$ at surface to $1 \mu \mathrm{g} \mathrm{m}^{-3}$ at $500 \mathrm{~m}$. These decreases are attributed mostly to the sharp decrease in the source strength. However, as there are no primary sources of BC over the ocean, this decrease is only marginal in the BoB profile.

- Above the convectively mixed region ( 500 to $700 \mathrm{~m}$ ), however, $\mathrm{M}_{\mathrm{B}}$ remained at a nearly steady level with altitude, with the lowest value over Hyderabad and highest off BBR.

- While the Hyderabad profile did not show any structures in the profile, KNP and BBR profiles showed a peak (though weak) at $\sim 800 \mathrm{~m}$. The KNP profile extended only upto $1800 \mathrm{~m}$. The profile off BBR shows the existence of small structures at even beyond $2 \mathrm{~km}$ AGL, which are mainly attributed to the thermodynamics of the atmosphere and long-range transport. As low-level clouds would be present at or even below $3 \mathrm{~km}$, our observations mean that significant amounts of $\mathrm{BC}$ would be with in and above clouds. This enhances the radiative forcing of the atmosphere, than if the entire $\mathrm{BC}$ were confined only within the ABL (Haywood and Ramaswamy 1998; Satheesh 2002).

It is also interesting to compare the altitude distribution $M_{B}$ with those reported from measurements made elsewhere by other investigators with special focus to the Asian region. Based on the C-130 aircraft experiments over Indian Ocean during INDOEX, Mayol Bracero et al (2002) indicated the presence of substantial amounts of $\mathrm{BC}$, as high as $\sim 6 \mu \mathrm{g} \mathrm{m}^{-3}$ at $2.9 \mathrm{~km}$, above the marine atmospheric boundary layer. From aircraft measurements during TRACE A experiment over Brazilian forests, very high values of $\mathrm{BC}$ upto $12 \mu \mathrm{g} \mathrm{m}^{-3}$ were reported at altitudes $2.5 \mathrm{~km}$ (Pereira et al 1996). Aircraft measurements during ACE-Asia over Sea of Japan, East China Sea, and Philippine Sea, by Mader et al (2002) showed that $\mathrm{M}_{\mathrm{B}}$ values below $3 \mathrm{~km}$ ranged from 0.20 to $1.8 \mu \mathrm{g} \mathrm{m}^{-3}$. Based on the measurements of $\mathrm{BC}$ onboard aircraft as a part of the Arctic Gas and Aerosol Sampling Program (AGASP) over Barrow, Alaska, Hansen and Rosen (1984) reported substantial concentrations of $\mathrm{BC}$ at all altitudes in the Arctic troposphere. They reported a very pronounced layer below $1 \mathrm{~km}$ altitude (with a peak concentration of $\sim 1.2 \mu \mathrm{g} \mathrm{m}^{-3}$ between 400 and $500 \mathrm{~m}$ altitude) and a substantial concentration of $0.1 \mu \mathrm{g} \mathrm{m}^{-3}$ upto $5 \mathrm{~km}$ during the flight conducted on 11 March 1983. During the flight conducted on 15 March 1983, even though the vertical distribution of $\mathrm{BC}$ was different, the total air column burden was similar to the former flight. During the AGASP-II conducted in April 1986, Hansen and Novakov (1989) observed BC values typically ranged from 0.3 to $0.5 \mu \mathrm{g} \mathrm{m}^{-3}$ at lower altitudes, decreasing gradually to 0.025 to $0.1 \mu \mathrm{g} \mathrm{m}^{-3}$ at 8 to $10 \mathrm{~km}$. Based on the measurements made during April 1992, Hansen et al (1997) reported an increase in $\mathrm{BC}$ concentrations from 0.1 to $0.2 \mu \mathrm{g} \mathrm{m}^{-3}$ below, to 0.8 to $1.0 \mu \mathrm{g} \mathrm{m}^{-3}$ above 850 hpa over East Siberian Sea $\left(\sim 74^{\circ} \mathrm{N}, 152^{\circ} \mathrm{E}\right)$.

\subsection{Latitudinal variation in $M_{B}$ : Land-ocean contrast}

With a view to examining the latitudinal variations of $\mathrm{BC}$ and its altitude structure, we conducted another sortie on March 27, 2006 (blue line in figure 1), during which the aircraft made a northsouth sampling over the $\mathrm{BoB}$, off $\mathrm{BBR}$ and $\mathrm{M}_{\mathrm{B}}$ was estimated for two heights, $500 \mathrm{~m}$ (within the $\mathrm{ABL}$ ) and $1500 \mathrm{~m}$ (above the ABL). During this, the aircraft covered a latitudinal span of $\sim 3.6^{\circ}$, which was much higher than the spatial coverage in the earlier sorties at HYD and KNP. The limit of the latitudinal coverage was basically due to the endurance of the aircraft. The results are shown in figure 6 . The flight originated from BBR (around $20.66^{\circ} \mathrm{N}$ ) and went southward over the BoB (upto $\sim 17.09^{\circ} \mathrm{N}$ ) crossing the coastline in between. As the instrument was operated with a timebase of 1 min and the aircraft was moving at a speed of $\sim 360 \mathrm{~km}$ per hour, measurements were available on an average at every $6 \mathrm{~km}$ along the track. At $500 \mathrm{~m}$ level, $\mathrm{M}_{\mathrm{B}}$ showed high values with large fluctuations over land as well as coastal regions over ocean (upto $19.2^{\circ} \mathrm{N}$ ) but very close to the mainland, about $50 \mathrm{~km}$ off the coastline (at $\sim 19.7^{\circ} \mathrm{N}$ ). In this region $\mathrm{M}_{\mathrm{B}}$ values varied between $1.0 \mu \mathrm{g} \mathrm{m}^{-3}$ and $5 \mu \mathrm{g} \mathrm{m}^{-3}$ with a mean value of $3.0 \pm 0.3 \mu \mathrm{g} \mathrm{m}^{-3}$. 


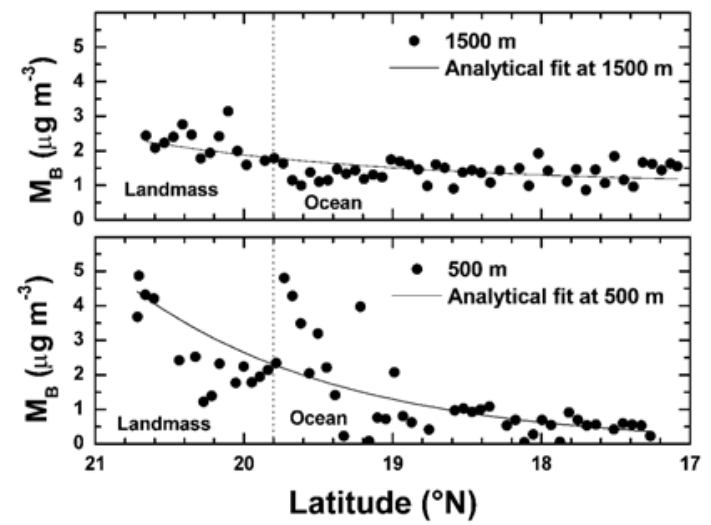

Figure 6. Latitudinal variation of $\mathrm{BC}$ mass concentration at $500 \mathrm{~m}$ level (bottom panel) and 1500 level (top panel) over $\mathrm{BoB}$ off BBR. The curves in each panel represent the best-fit exponential growth curves to the measurements. The dotted vertical line parallel to the $\mathrm{Y}$-axis represents the coastline that separates the landmass from the ocean. The abscissa is shown with the starting point of the sortie as origin and latitude decreasing to the right.

Table 1. Latitudinal gradient of $M_{\mathrm{B}}$ at 500 and $1500 \mathrm{~m}$.

\begin{tabular}{clllc}
\hline Altitude & $\mathrm{A}$ & \multicolumn{1}{c}{$\mathrm{B}$} & $\Lambda_{D}($ in $\mathrm{km})$ & $R^{2}$ \\
\hline 500 & 0 & 0.0016 & $140 \pm 20.0$ & 0.57 \\
1500 & 1.03 & 0.0067 & $170 \pm 100.5$ & 0.44 \\
\hline
\end{tabular}

The large fluctuations are attributed to the local emission, being mixed by the turbulent eddies arising from thermal convection. Further to the south, over the ocean, $M_{B}$ values reduced significantly to below $1 \mu \mathrm{g} \mathrm{m}^{-3}$, still showing minor variations (between $0.05 \mu \mathrm{g} \mathrm{m}^{-3}$ and $1 \mu \mathrm{g} \mathrm{m}^{-3}$ with a mean value of $\left.0.9 \pm 0.14 \mu \mathrm{g} \mathrm{m}^{-3}\right)$. At $1500 \mathrm{~m}$ level, however the variations were considerably reduced because the impacts due to local sources and turbulent mixing are well shielded by the capping inversion at $\sim 700 \mathrm{~m}$ and showed a mean value of $2.2 \pm 0.1 \mu \mathrm{g} \mathrm{m}^{-3}$ over land. Over the ocean the values were lower (between $1 \mu \mathrm{g} \mathrm{m}^{-3}$ and $2 \mu \mathrm{g} \mathrm{m}^{-3}$ ) with a mean value of $1.35 \pm 0.04 \mu \mathrm{g} \mathrm{m}^{-3}$. (The values given after the \pm symbol for each mean value are the standard deviation of the mean). However, the land-ocean contrast in $\mathrm{M}_{\mathrm{B}}$ is highly subdued at $1500 \mathrm{~m}$ compared to that at $500 \mathrm{~m}$ level.

The latitudinal variations in $\mathrm{M}_{\mathrm{B}}$ at $500 \mathrm{~m}$ level and $1500 \mathrm{~m}$ level, shown in figure 6 , have been parameterized using an exponential growth function of the form

$$
\mathrm{M}_{\mathrm{B}}(\Lambda)=A+B \exp \left(\frac{\Lambda}{\Lambda_{D}}\right)
$$

where $A$ is an offset (which might represent the non-local contribution to $\mathrm{BC}$ ), $\mathrm{M}_{\mathrm{B}}(\Lambda)$ is the value of $\mathrm{M}_{\mathrm{B}}$ at latitude $\Lambda^{\circ}, B$ is the amplitude and $\Lambda_{D}$ is the scaling length for an e-fold growth. The solid line in figure 6 represents the fit to equation (4) through the measurement points. A good fit is apparent with moderate to high values of squared correlation coefficients $\left(R^{2}\right)$, which are given in table 1 , along with other parameters of equation (4).

The table shows that the variation at $500 \mathrm{~m}$ level has little offset, and the distribution is mostly attributed to local effects (like local sources and convective mixing). As such, it has a much shorter scaling length, implying steeper gradient, and has a higher correlation to the analytical function. Compared to this, at $1500 \mathrm{~m}$, there is a significant non-local contribution of $\sim 1 \mu \mathrm{g} \mathrm{m}^{-3}$ of $\mathrm{BC}$ (which could be attributed to the long range transport and/or the background) over which there is a much slower spatial variation with a longer scale length of $170 \mathrm{~km}$. This non-local contribution to aerosol loading at higher levels have been observed along the east coast of India and in the IGP in earlier studies also (Nair et al 2007; Niranjan et al 2007), who have attributed this to advection from the continental regions including west Asia and north west India. These non-local sources appear to play a major role in determining $\mathrm{BC}$ concentrations at higher altitudes.

Another interesting feature revealed in figure 6 is that while at $500 \mathrm{~m}$ level $\mathrm{M}_{\mathrm{B}}$ over the land was always higher than $1 \mu \mathrm{g} \mathrm{m}^{-3}$ and over ocean it was always less than $1 \mu \mathrm{g} \mathrm{m}^{-3}$; at the $1500 \mathrm{~m}$ (above the convective boundary layer) the scenario was different, with $\mathrm{M}_{\mathrm{B}}$ values over the ocean being always higher than the corresponding value at $500 \mathrm{~m}$ (over the entire latitude region covered). In other words, over the ocean, $\mathrm{M}_{\mathrm{B}}$ at $1500 \mathrm{~m}$ was higher than that at $500 \mathrm{~m}$, again confirming non-local sources contributing to $\mathrm{M}_{\mathrm{B}}$ in the free troposphere. In the latitudinal variation of $\mathrm{BC}$ reported by Moorthy et al (2004) and Tripathi et al (2005) over the inland stations (though in their studies the latitudinal coverages were much shorter and the measurements were confined only over the landmass) we note that, while over Hyderabad Moorthy et al (2004) reported a weak increasing trend within the $\mathrm{ABL}$, as the aircraft moved out of the urban centre, they did not find any gradient at higher altitudes. Tripathi et al (2005), on the other hand, reported a weak decreasing trend with latitude, as the aircraft moved out of the industrial area towards the rural area, at $300 \mathrm{~m}$ and $600 \mathrm{~m}$ altitudes. However, at $900 \mathrm{~m}$ altitude, they reported a weak increasing trend similar to the pattern seen off BBR. It suggests the possibility of regional differences in the 
latitudinal gradients, caused apparently by longrange transport.

\subsection{Implications}

As stated earlier, the altitude distribution of $\mathrm{BC}$ has important implications in aerosol radiative forcing and the influence of $\mathrm{BC}$ on cloud properties. Tripathi et al (2005) have reported that the difference in the short-wave, clear sky forcing between the steadily decreasing and increasing $\mathrm{BC}$ aloft is as much as a factor of 1.3. Lubin et al (2002) have shown that this difference can be as much as a factor of two in the case of long wave. Haywood and Ramaswamy (1998) have reported from GCM simulation that the direct radiative forcing of a $\mathrm{BC}$ aerosol layer increases approximately by a factor of 5 , as the layer is moved between the surface and $20 \mathrm{~km}$. Satheesh (2002) reported that the elevated BC layer over landmass with high reflectance or over scattering aerosol/cloud layer will enhance the atmospheric forcing and can even reverse the 'white house effect' of aerosols. Based on model simulation and observation during INDOEX, Ackerman et al (2000) reported that enhanced layer of $\mathrm{BC}$ aerosols reduce the cloud cover by $\mathrm{BC}$ induced atmospheric heating and hence offset the aerosol induced radiative cooling at the top of the atmosphere on a regional scale.

\section{Conclusions}

Altitude distribution of the mass concentrations of aerosol black carbon over the BoB off Bhubaneswar (BBR) was obtained at high spatial resolution. In addition, the latitudinal gradients in $\mathrm{M}_{\mathrm{B}}$ at different altitude regions (within and above ABL) were examined. The investigation revealed:

- A nearly steady vertical distribution of $\mathrm{M}_{\mathrm{B}}$ superposed with small fluctuations lead to two peaks (at $800 \mathrm{~m}$ and $2000 \mathrm{~m}$ ) over the mean value of $1.43 \pm 0.06 \mu \mathrm{g} \mathrm{m}^{-3}$.

- Examination of the vertical structure of the atmosphere using high resolution GPS sonde ascents over the same region show that these peaks were associated with the occurrence of temperature inversions; the lower one occurring around the region of the top of the convective marine atmospheric boundary layer while the peak at $2000 \mathrm{~m}$ was associated with the elevated inversion.

- Significant amount of BC is observed above the MABL, even beyond $2 \mathrm{~km}$.

- A comparison of the profile obtained over BoB off BBR with those reported over the continental locations (Hyderabad and Kanpur) in earlier investigations showed that while the profile over the inland locations showed sharp decrease in concentration with height within the ABL (upto $\sim 500 \mathrm{~m}$ ) probably due to sharp decline in local surface impacts the decrease was much weaker over the BoB. Above the ABL, nearly the same value of $1 \mu \mathrm{g} \mathrm{m}^{-3}$ were observed at all the locations suggesting significant quantities of elevated BC.

- Latitudinal distribution of $\mathrm{M}_{\mathrm{B}}$ shows that at $500 \mathrm{~m}$ level, $\mathrm{M}_{\mathrm{B}}$ over land is always higher than $1 \mu \mathrm{g} \mathrm{m}^{-3}$ and over ocean it is always less than $1 \mu \mathrm{g} \mathrm{m}^{-3}$; at $1500 \mathrm{~m}$ the scenario was different, with $\mathrm{M}_{\mathrm{B}}$ values over ocean being always higher than the value at $500 \mathrm{~m}$, over the latitude region covered. Parameterization of the latitudinal distribution in $\mathrm{M}_{\mathrm{B}}$ using an exponential function gave a shorter scaling length with very little offset at $500 \mathrm{~m}$ showing the influence of local effects in the distribution of $\mathrm{M}_{\mathrm{B}}$. At $1500 \mathrm{~m}$, the spatial variation is slower with longer scale length and significant offset showing a substantial amount of $\mathrm{M}_{\mathrm{B}}$ of non-local origin, which confirms the role of long-range transport at higher altitude.

- Back trajectory analysis showed strong pathways favouring advection from western landmass to contribute significantly to the $\mathrm{BC}$ concentration above ABL. The ABL structure along with the latitude gradient and back trajectory analysis showed that, while local sources contribute significantly to $\mathrm{M}_{\mathrm{B}}$ and its variations within the ABL (below $800 \mathrm{~m}$ ), long-range transport and non-local sources attribute significantly to $\mathrm{M}_{\mathrm{B}}$ at higher levels.

\section{Acknowledgements}

This work formed a part of the ICARB experiment of ISRO-GBP. The authors wish to thank the crew of the aircraft for their help throughout the field campaign and their wholehearted support of the NRSA aircraft team headed by Dr. K Kalyanaraman and Mr. Raghu Venkataraman. We acknowledge the NOAA Air Resources Laboratory for the provision of the HYSPLIT transport and dispersion model and READY website (http://www.arl.noaa.gov/ready.html) used in this publication.

\section{References}

Ackerman A S, Toon O B, Stevens D E, Heymsfield A J, Ramanathan V and Welton E J 2000 Reduction of tropical cloudiness by soot; Science 288 1042-1047. 
Arnott W P, Hamasha K, Moosmuller H, Sheridan P J and Ogren J A 2005 Towards aerosol light-absorption measurements with a 7 -wavelength aethalometer: Evaluation with a photoacoustic instrument and 3-wavelength Nephelometer; Aerosol Sci. Technol. 39(1) 17-29.

Babu S S and Moorthy K K 2002 Aerosol black carbon over tropical coastal station in India; Geophys. Res. Lett. 29 doi: 10.1029/2002GL015662.

Beegum N, Moorthy K K, Nair V S, Babu S S, Satheesh S K, Vinoj V, Reddy R R, Gopal K R, Badarinath K V S, Niranjan K, Pandey S K, Behera M, Jeyaram A, Bhuyan P K, Gogoi M M, Singh S, Pant P, Dumka U C, Kant Y, Kuniyal J C and Singh D 2008 Characteristics of Spectral Aerosol Optical Depths over India during ICARB; J. Earth Syst. Sci. (this issue).

Blake D F and Kato K 1995 Latitudinal distribution of black carbon soot in the upper troposphere and lower stratosphere; J. Geophys. Res. 100 7195-7202.

Clarke A D et al 2004 Size distributions and mixtures of dust and black carbon aerosol in Asian outflow: Physiochemistry and optical properties; J. Geophys. Res. 109 D15S09, doi:10.1029/2003JD004378.

Corrigan C E, Ramanathan V and Scauer J J 2006 Impact of monsoon transitions on the physical and optical properties of aerosols; J. Geophys. Res. 111 D18208, doi:10.1029/2005JD006370.

Hansen A D A 1996 Magee Scientific Aethalometer User's Guide; Magee Sci., Berkeley, California, 56pp.

Hansen A D A and Rosen H 1984 Vertical distributions of particulate carbon, sulfur, and bromine in the Arctic haze and comparison with ground level measurements at Barrow, Alaska; Geophys. Res. Lett. 11 381-384.

Hansen A D A and Novakov T 1989 Aerosol Black Carbon measurements in the Arctic Haze during AGASP-II; J. Atmos. Chem. 9 347-361.

Hansen A D A, Polissar A V and Schnell R C 1997 Airborne aerosol and black carbon measurements over the East Siberian Sea, Spring 1992; Atoms. Res. 44 153-165.

Haywood and Ramaswamy 1998 Global sensitivity studies of the direct forcing due to anthropogenic sulfate and black carbon aerosols; J. Geophys. Res. 103 6043-6058.

Jacobson M Z 2001 Strong radiative heating due to mixing state of black carbon in the atmospheric aerosols; Nature 409 695-697.

Lohmann U, Feichter J, Penner J and Leatch R 2000 Indirect effect of sulfate and carbonaceous aerosols: A mechanistic treatment; J. Geophys. Res. 105 12,193-12,206.

Lubin D, Satheesh S K, McFarquar G and Heymsfield A J 2002 Longwave radiative forcing of Indian Ocean tropospheric aerosol; J. Geophys. Res. 107(D19) 8004, doi: 10.1029/2001JD001183

Mader B T, Flagan R C and Seinfeld J H 2002 Airborne measurements of atmospheric carbonaceous aerosols during ACE-Asia; J. Geophys. Res. 107 (D23), doi: 10.1029/2002JD002221.

Mayol-Bracero O L, Gabriel R, Andreae M O, Kirchstetter $\mathrm{T}$ W, Novakov $\mathrm{T}$, Ogren J, Sheridan $\mathrm{P}$ and Streets D G 2002 Carbonaceous aerosols over the Indian Ocean during the Indian Ocean Experiment
(INDOEX): Chemical characterization, optical properties, and probable sources; J. Geophys. Res. 107(D19) 8030, doi:10.1029/2000JD000039.

Möhler O et al 2005 Effect of sulfuric acid coating on heterogeneous ice nucleation by soot aerosol particles; J. Geophys. Res. 110 D11210, doi:10.1029/2004JD005169.

Moorthy K K, Satheesh S K and Babu S S 2006 ICARB - An integrated campaign for Aerosols, gases and Radiation Budget over India; Proc. of SPIE 6408 64080P-1.

Moorthy K K, Babu S S, Kumar S V S, Gupta P K and Geera B S 2004 Altitude profiles of aerosol BC derived from aircraft measurements over an inland urban location in India; Geophys. Res. Lett. 31 L22103, doi: 10.1029/2004GL021336.

Moorthy K K, Satheesh S K, Babu S S and Dutt C B S 2008 Integrated Campaign for Aerosols, gases and Radiation Budget (ICARB): An Overview; J. Earth Syst. Sci. (this issue).

Nair V S, Moorthy K K, Alappattu D P, Kunhikrishnan P K, George S, Nair P, Babu S S, Abish B, Satheesh S K, Tripathi S N, Niranjan K, Madhavan B L, Srikant V, Dutt C B S, Badarinath K V S and Ramakrishna Reddy R 2007 Wintertime aerosol characteristics over the Indo Gangetic Plain (IGP): Impacts of local boundary layer processes and long-range transport; J. Geophys. Res. 112 D13205, doi: 10.1029/ 2006.JD008099.

Niranjan K, Madhavan B L and Sreekanth V 2007 Micro pulse lidar observation of high altitude aerosol layers at Visakhapatnam located on the east coast of India; Geophys. Res. Lett. 34 L03815, doi: 10.1029/2006GL028199.

Pereira E B, Setzer A B, Gereb F, Artaxo P E, Pereira M C and Monore G 1996 Airborne measurements of aerosols from burning biomass in Brazil related to Trace A experiment; J. Geophys. Res. 101 23,983-23,992.

Pueschel R F et al 1992 Black carbon (soot) aerosol in the lower stratosphere and upper troposphere; Geophys. Res. Lett. 19(16) 1659-1662.

Satheesh S K, Vinoj V and Moorthy K K 2006 Vertical distribution of aerosols over an urban continental site in India inferred using a micro pulse lidar; Geophys. Res. Lett. 33 L20816, doi: 10.1029/2006GL027729.

Satheesh S K 2002 Aerosol radiative forcing over land: effect of surface and cloud reflection; Ann. Geophys. 20 $1-5$.

Sheridan P J et al 2005 The Reno Aerosol Optics Study: An evaluation of aerosol absorption measurement methods; Aerosol Sci. Technol. 39 1-16.

Strawa A W et al 1999 Carbonaceous aerosol (soot) measured in the lower stratosphere during POLARIS and its role in stratospheric photochemistry; J. Geophys. Res. 104(D21) 26,753-26,766.

Tripathi S N, Dey S, Tare V, Satheesh S K, Lal S and Venkataramani S 2005 Enhanced layer of black carbon in a north Indian industrial city; Geophys. Res. Lett. 32 L12802, doi: 10.1029/2005GL022564.

Weingartner E, Saathoff H, Schnaiter M, Strit N, Bitnar B and Baltensperger U 2003 Absorption of light by soot particles: determination of the absorption coefficient by means of aethalometers; J. Aerosol Sci. 34 1445-1463. 